\title{
Pilihan Allah Atas Israel: Masih Relevankah di Masa Kini?
}

\section{Jannen Ridwan Pangaribuan}

Prodi PAK STT Tabernakel Indonesia

email: jannen.pangaribuan@sttia.ac.id

\begin{tabular}{l}
\hline INFO ARTIKEL \\
\hline Sejarah artikel: \\
Dikirim 14 Oktober 2021 \\
Direvisi 31 Desember 2021 \\
Diterima 31 Desember 2021 \\
Terbit 31 Desember 2021 \\
\hline Kata kunci: \\
Israel \\
Pemilihan \\
Teologi Penggantian \\
Teologi Pemisahan \\
Teologi Sisa
\end{tabular}

Keywords:

Israel

Election

replacement theology

separation theology

remnant theology

\begin{tabular}{l} 
ABSTRAK \\
\hline Apakah masih relevan untuk membicarakan pilihan Allah atas Israel \\
pada masa kini? Eksistensi Israel hingga masa kini selalu dikaitkan \\
dengan statusnya sebagai bangsa pilihan Allah. Berkembang tiga \\
pemahaman terhadap pilihan Allah atas Israel yang masing-masing \\
memiliki konsekuensi teologis, yakni pertama dari sudut pandang \\
teologi penggantian; kedua dari sudut pandang teologi pemisahan dan \\
ketiga dari sudut pandang teologi sisa. Ketiga pandangan ini akan \\
dikritisi dan diperbandingkan untuk melihat relevansi pilihan Allah \\
atas Israel sebagai bangsa hingga pada masa kini. Penelitian dilakukan \\
dengan metode penelitian studi pustaka terhadap ketiga pandangan \\
teologis terhadap pilihan atas bangsa Israel. Ditemukan bahwa \\
pandangan teologi sisa memberi pemahaman yang lebih sesuai dengan \\
konsep biblika terhadap pemilihan Allah atas Israel. Pandangan ini juga \\
memberi arahan terhadap sikap yang tepat dalam hubungannya \\
dengan konflik yang masih terus terjadi di Timur Tengah berkaitan \\
dengan tanah Palestina. \\
\hline ABSTRACT \\
\hline Is it still relevant talking about God's choice of Israel today? Their existence is \\
always associated with their status as God's chosen people. Three perspectives \\
of God's choice of Israel have developed, each of which has theological \\
consequences, namely, first from the view of replacement theology; second from \\
the view of separation theology, and third from the view of remnant theology. \\
These three views will be criticized and compared to see the relevance of God's \\
election towards Israel as a nation today. The research was conducted using a \\
literature study method on the three theological views on the election of the \\
Israelites. It was found that the remnant theological view provides a more \\
appropriate understanding of the biblical concept of God's election of Israel. \\
This view also gives direction to the right attitude in relation to the ongoing \\
conflict in the Middle East regarding the land of Palestine. \\
\hline
\end{tabular}

\section{PENDAHULUAN}

Masih relevankah membicarakan pilihan Allah atas Israel sebagai umat Allah pada masa kini? Suatu pertanyaan yang mengemuka ketika Israel kembali eksis sebagai suatu bangsa, sebab sudah sekitar 2.500 tahun lamanya Israel kehilangan tanah air dan tersebar di antara bangsa-bangsa (diaspora). Mereka pada masa lalu terbuang dari tanahnya, lalu di tanah 
asing pun mereka masih dikejar-kejar untuk dimusnahkan sebagai suatu bangsa. ${ }^{1}$ Setelah 400 tahun di bawah kekuasaan Ottoman, ${ }^{2}$ pada tahun 1948 akhirnya bangsa Israel menyatakan diri sebagai bangsa merdeka di tanah airnya (Palestina). Hal ini setelah peristiwa holocaust yang sangat mengerikan yang dilakukan oleh Nazi Jerman terhadap orang Yahudi di bawah komando Adolf Hitler. Lebih dari 6 juta orang Yahudi di Eropa mati dalam genosida yang kejam ini. Holocaust membekas dalam ingatan bangsa Israel. ${ }^{3}$

Pada tahun 1967 (lewat perang 6 hari) Israel tidak hanya menjadi bangsa yang merdeka, tetapi juga berhasil menguasai Yerusalem kembali, dan pada tahun 1980 kota Yerusalem resmi menjadi ibukota negara Israel. Namun hal itu belum berarti bahwa Israel telah mengalami masa damai, terlebih dengan berdirinya organisasi-organisasi perjuangan Palestina seperti Hamas yang ingin merebut kembali tanah Palestina. Masing-masing pihak memiliki persepsi atas damai yang berbeda yang justru mempertahankan konflik berkepanjangan, ${ }^{4}$ di samping persepsi damai dari persoalan sosial budaya. ${ }^{5}$ Pada bulan Mei 2021 yang lalu Israel telah dihujani kembali dengan serangan roket yang dilancarkan oleh Hamas setelah terjadi kerusuhan dekat Temple Mount di sekitar Mesjid Al Aqsa. ${ }^{6}$ Tindakan yang kemudian dibalas oleh pihak Israel dengan menyerang Gaza melalui serangan udara. Perang yang disiarkan secara intens oleh media massa online ini tentunya menyebarkan perang ini ke seluruh dunia. ${ }^{7}$ Pro kontra terhadap Israel kembali terjadi. Tetapi sampai hari ini Israel masih tetap eksis. Faktor pilihan Allah dianggap menjadi pertimbangan eksistensi terhadap Israel sebagai bangsa. ${ }^{8}$ Israel adalah bangsa pilihan Allah dan Allah sendiri seperti dikatakan oleh Rasul Paulus tidak menolak umat yang telah Ia kenal sebelumnya (Rom.11:2). Allah sendiri yang mengikat suatu perjanjian (berit) dengan umat Israel melalui nenek moyang Abraham (Kej.17:13) dan meneguhkannya di gunung Sinai sebagai perjanjian kekal (Kel.19:36).

\footnotetext{
${ }^{1}$ Tito Hilmawan Reditya, "Kekejaman Holocaust Nazi, Korban 'Dikemas Seperti Sarden,'” Kompas.Com.

${ }^{2}$ History.Com Editors, "Israel," last modified 2017, https://www.history.com/topics/middleeast/history-of-israel.

${ }^{3}$ Yechiel Klar, Noa Schori-Eyal, and Yonat Klar, "The 'Never Again' State of Israel: The Emergence of the Holocaust as a Core Feature of Israeli Identity and Its Four Incongruent Voices," Journal of Social Issues 69, no. 1 (March 2013): 125-143, https://onlinelibrary.wiley.com/doi/10.1111/josi.12007.

4Maia Hallward and By Maia Hallward, "Pursuing \&quot;Peace\&quot; in Israel/Palestine," Journal of Third World Studies 28, no. 1 (2011): 185-202, http://digitalcommons.kennesaw.edu/facpubs.

5Ilmi Dwiastuti, "The Roots of Israel-Palestine Conflict: A Political Culture Analysis," AEGIS : Journal of International Relations 4, no. 2 (2021): 19-33.

'Reuters, "Sejarah Panjang Konfrontasi Hamas Dan Israel," Www.Voaindonesia.Com, last modified 2021, accessed September 1, 2021, https://www.voaindonesia.com/a/sejarah-panjangkonfrontasi-hamas-dan-israel/5901008.html.

${ }^{7}$ Eugenia Siapera, Graham Hunt, and Theo Lynn, “\#GazaUnderAttack: Twitter, Palestine and Diffused War," Information Communication and Society 18, no. 11 (2015): 1297-1319.

8 Uriel Abulof, "The Roles of Religion in National Legitimation: Judaism and Zionism's Elusive Quest for Legitimacy," Journal for the Scientific Study of Religion 53, no. 3 (September 3, 2014): 515-533, http://www.jstor.org/stable/24644225.
}

112 - J.R. Pangaribuan, Pilihan Allah Atas Israel: Masih Relevankah di Masa Kini? 
Dalam Perjanjian Baru, Gereja disebut sebagai “bangsa yang kudus, umat kepunyaan Allah sendiri" (1 Ptr.1:9) predikat yang sebelumnya secara eksklusif disematkan kepada bangsa Israel (Kel.19:5-6). Hal ini tentunya menimbulkan pertanyaan mengenai relevansi pilihan Allah atas bangsa Israel, apakah posisi Israel sebagai pilihan Allah sudah berakhir dan telah digantikan oleh Gereja? Ataukah memang Allah memiliki dua program, yakni program bagi Israel dan program bagi Gereja seperti dipahami dalam teologi dispensasional? Ataukah pilihan itu tetap berkelanjutan di antara orang-orang Israel yang tersisa dalam suatu "Israel baru" yakni Gereja seperti dianut dalam remnant theology? Jawaban terhadap pertanyaanpertanyaan ini akan memberi gambaran sikap Kristiani dalam menyikapi konflik yang selalu timbul di Timur Tengah dalam kaitannya dengan tanah Palestina dan Israel sebagai suatu bangsa.

\section{METODE}

Untuk menjawab pertanyaan-pertanyaan di atas maka akan dilakukan penelitian berdasarkan kajian literatur terhadap perkembangan ketiga pemahaman yang berkembang dan melakukan analisa kritis dan perbandingan terhadap ketiga pandangan tersebut dalam literatur teologi untuk mendapatkan pemaknaan yang lebih baik terhadap konsep pemilihan yang akan menjawab pertanyaan mengenai relevansi pemilihan Allah atas Israel pada masa kini.

\section{HASIL DAN PEMBAHASAN}

\section{Pandangan Pandangan Perjanjian Baru Terhadap Israel sebagai Pilihan Allah}

Bangsa Israel telah dipilih untuk menurunkan Mesias, Tuhan dan Juruselamat manusia (Rom.9:4-5). Walaupun menurut Injil Bangsa Yahudi sendiri sejak semula menolak Yesus sebagai Mesias dan sudah merancang rencana untuk membunuh-Nya (Mat.26:3-4; Mrk.14:1-2; Luk.22:1-2; Yoh.11:49-50; 18:12-14) yang kemudian terealisasi dengan menyalibkan Yesus. Tuduhan ini ditegaskan oleh Rasul Petrus sendiri bahwa orang Yahudilah yang telah menyalibkan Yesus (Kis.2:23; 4:10-11; 5:20), demikian juga disampaikan oleh Stefanus yang kemudian dilempari dengan batu hingga mati (Kis.7:53). Ketika Yesus bangkit menggenapi nubuat para nabi, orang Yahudi menurut Matius berusaha menutupi berita kebangkitan-Nya dan mengarang kisah lain bahwa para murid-Nyalah yang telah mencuri jasad-Nya (Mat.28:11-15). Ketika Gereja Yesus Kristus berkembang oleh pemberitaan muridmurid Yesus, orang-orang Yahudi kembali berusaha menghambatnya dengan menganiaya para pemimpin Gereja dan jemaat Kristen (Kis.4:15-17; 5:17-18, 40; 7:54-59; 8:1-3). Hal ini kontras dengan kedudukan bangsa Yahudi sebagai bangsa pilihan Allah yang justru menolak dan menyalibkan utusan Allah, bahkan Anak Allah sendiri (Yoh.1:11).

Paulus menyoroti kedudukan Israel dalam Perjanjian Baru dalam hubungannya dengan bangsa-bangsa lain yang telah menjadi percaya dan masuk dalam bilangan Gereja. Paulus menunjukkan sikapnya yang tidak apriori bahwa Allah telah menolak umat-Nya, dia 
sendiri berkata bahwa "aku sendiri adalah orang Yahudi" (Rom.11:1). Paulus adalah seorang yang termasuk salah satu pemimpin dari para penganiaya itu dulunya, tetapi justru kemudian menjadi percaya kepada Yesus sebagai mesias. Tetapi dalam hal penerimaan terhadap bangsabangsa lain ini di kalangan para pemimpin gereja di Yerusalem sendiri menunjukkan sikap yang mendua, seperti dilakukan oleh Rasul Petrus dengan bersikap menolak bersekutu dengan orang-orang percaya dari bangsa-bangsa lain (Gal.3:11-14). Gereja di Yerusalem memang kemudian menerima bangsa-bangsa lain dalam Gereja tetapi menekankan supaya mereka mempertahankan warna Yahudi dengan menaati Taurat seperti sunat, hal yang ditentang oleh Rasul Paulus. Hal ini mendorong diadakannya konsili di Yerusalem dengan keputusan bersama untuk saling menghormati (Kis.15:13-21).

Dalam tulisan-tulisannya Paulus menunjukkan bahwa bangsa Israel yang menerima Yesus saat itu sebagai Mesias yang jumlahnya tidak banyak, sehingga patut disebut sebagai kaum sisa ( $\lambda \varepsilon \tilde{u} \mu \mu a)$, pilihan kasih karunia (Roma 11:5). Saat itu jumlah yang percaya dari kalangan Yahudi dan dibaptis disebutkan berjumlah 120 orang (Kis.1:15) lalu bertambah menjadi 3.000 orang (2:41), tiap-tiap hari jumlah ini bertambah lagi (2:47) hingga jumlahnya

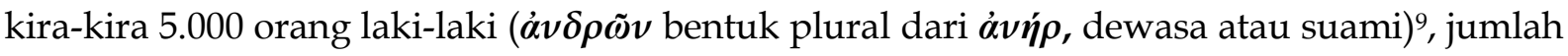
ini belum turut dihitung perempuan dan anak-anak. (Diperkirakan saat itu bahwa orang Yahudi di Kekaisaran Romawi pada abad pertama berjumlah kira-kira 4-5 juta jiwa.) ${ }^{10}$ Namun ketika terjadi serangan atas Yerusalem oleh Romawi di bawa komando Jenderal Titus dan menghancurkan Bait di sana, orang-orang Kristen kemudian tersebar dan berakhirlah masa kekristenan di Yerusalem. Pusat kekristenan lalu bergeser ke Antiokhia. ${ }^{11}$

Dalam memandang Gereja, Paulus selalu mempertimbangkan eksistensi dari bangsabangsa lain ini sebagai yang sudah diterima oleh Allah di dalam perjanjian oleh Yesus Kristus dan menyebut Gereja yang terdiri dari bangsa Israel (Yahudi) dan memandangnya dalam kesatuan umat Perjanjian Baru. Israel menurut Paulus tidak lagi dipandang dari sisi kebangsaannya, tetapi dari imannya. Hal ini jelas disebutkan dalam Roma 9:6-8, “...bahwa bukan anak-anak menurut daging adalah anak-anak Allah, tetapi anak-anak perjanjian yang disebut keturunan yang benar." Komunitas Kristen mula-mula mengindentifikasikan dirinya sendiri dengan Israel sebagai umat Allah dengan mengaplikasikan secara langsung nama Israel pada Gereja Kristen mula-mula seperti dalam Galatia 6:16.12 Istilah “Israel milik Allah" merujuk kepada komunitas Kristen mula-mula yang menerima Injil seperti yang diberitakan Paulus. ${ }^{13}$

9 BibleWorks, “BibleWorks 8," 2018.

${ }^{10}$ Don Fanning, "Apostolic History of the Early Church," History of Global Missions (2009), https://digitalcommons.liberty.edu/cgm_hist/1\%0A.

${ }^{11}$ Ibid.

${ }^{12}$ Walaupun ada yang memandang bahwa pandangan ini lemah, Israel di sini lebih menunjuk kepada Israel secara etnis. S Lewis Johnson, "Paul and ' the Israel of God ': An Exegetical and Eschatological Case-Study," Master's Seminary Journal 1, no. Spring (2009): 41-55.

${ }^{13}$ Leland Ryken, James C. Wilhoit, and Tremper Longman III, Kamus Gambaran Alkitab (Surabaya: Momentum, 2011), 418.

114 - J.R. Pangaribuan, Pilihan Allah Atas Israel: Masih Relevankah di Masa Kini? 


\section{Israel dalam Sejarah Gereja: Berkurangnya Peran Bangsa Yahudi}

Gereja telah berdiri sebagai hasil dari misi penginjilan yang dilakukan oleh para Rasul dan para murid gereja mula-mula yang notabene adalah orang-orang Yahudi (Mat.28:18-20; Kis.1:8). Pada mulanya Gereja sebagian besar adalah berwarna Yahudi karena mayoritas berasal dari orang-orang Yahudi yang percaya. Gereja rasuli berkembang dalam naungan agama Yahudi, kekristenan dianggap sebagai suatu golongan atau mazhab Yahudi. ${ }^{14}$ Tetapi kemudian dengan menyebarnya kekristenan dan misi penginjilan oleh gereja mula-mula yang sampai kepada bangsa-bangsa lain maka persentase bangsa Yahudi dalam Gereja semakin mengecil, identifikasi gereja dengan Israel menjadi lebih sulit dan membutuhkan kreatifitas teologis. Ketika semakin banyak bangsa non Yahudi datang kepada iman, akar keyahudian gereja mulai terlupakan, justru dalam yang perkembangan selanjutnya banyak dipengaruhi oleh hellenisme.

Bahkan dalam gereja sendiri berkembang gerakan anti Semit. Hal ini terjadi sebab sikap dari bangsa Yahudi sendiri yang jelas menolak Yesus Kristus sebagai Mesias yang dijanjikan diikuti dengan sikap konfrontatifnya terhadap Gereja. Benih gerakan anti semit di Eropa sendiri berasal dari para reformator sendiri. Martin Luther (1483-1586) yang mencoba membawa gereja non Yahudi ke akar kekristenan tidak mendapat respon dari orang-orang Yahudi. ${ }^{15} \mathrm{Hal}$ ini membuatnya sangat frustasi dan ia menjadi seorang yang anti Semit. ${ }^{16}$ Dalam tulisan-tulisannya ia menyebut orang Yahudi sebagai "lebih buruk dari si jahat", orang Yahudi adalah "racun-racun pembunuh ritual" dan "parasit" yang harus dihapuskan dari Jerman. Apa yang sudah dia lakukan telah membangkitkan suatu gerakan liar untuk "membakar sinagoge rata dengan tanah" dan "merazia buku-buku Yahudi". ${ }^{17}$ Kemudian, Adolf Hitler mengatakan kepada orang-orang Jerman bahwa Solusi Akhir-nya hanyalah sebuah usaha untuk menyelesaikan pekerjaan yang telah dimulai oleh Luther. ${ }^{18}$

Tetapi sebenarnya masih terdapat orang-orang Yahudi yang percaya sepanjang sejarah gereja, umumnya disebut Yahudi Mesianik. ${ }^{19}$ Bahkan gerakan ini menunjukkan perkembangannya, saat ini di Israel kelompok ini menunjukkan eksistensinya sehingga dapat menjadi perwakilan dari bangsa Yahudi dalam sejarah gereja modern. Tahun 2008 menurut

${ }^{14}$ Dietrich Kuhl, Sejarah Gereja 1: Gereja Mula-Mula Di Dalam Lingkungan Kebudayaan Yunani Romawi (30-500) (Batu: Departemen Literatur, Yayasan Persekutuan Pekabaran Injil Indonesia, 1992), 34.

${ }^{15}$ Carty, "Martin Luther's Anti-Judaism and Its Political Significance," Antisemitism Studies 3, no. 2 (2019): 317, https:/ / www.jstor.org/stable/10.2979/antistud.3.2.06.

${ }^{16}$ Martin Hauger, "Martin Luther and the Jews: How Protestant Churches in Germany Deal with the Reformer's Dark Side," Theology Today 74, no. 3 (October 24, 2017): 225-234, http://journals.sagepub.com/doi/10.1177/0040573617721913.

${ }^{17}$ Michel Coren, "The Reformation at 500: Grappling with Martin Luther's Anti-Semitic Legacy," last modified 2017, https://www.macleans.ca/opinion/the-reformation-at-500-grappling-withmartin-luthers-anti-semitic-legacy/.

18United States Holocaust Memorial Museum, "Final Solution Overview," Holocaust Encyclopedia, n.d., https://encyclopedia.ushmm.org/content/id/article/final-solution-overview.

19Tamar "Who Are 'Jews'?," https://www.myjewishlearning.com/article/messianic-judaism/. 
Wikipedia jumlah pemeluknya (tidak semuanya orang Yahudi) di Amerika Serikat sebanyak 250.000 orang, sementara di Israel sendiri berjumlah 5.000 sampai 15.000 orang. ${ }^{20}$

\section{Pandangan-pandangan Teologis Terhadap Hubungan Antara Gereja dan Israel}

Ada tiga pandangan yang berbeda mengenai hubungan antara Gereja dan Israel:21 Pertama, Teologia Penggantian (Replacement) sebagai kristalisasi sikap dari dari Teologia Perjanjian yang memandang Gereja sebagai kelanjutan dari Israel. Kedua, pandangan Teologi Keterpisahan (Separation) sebagai kristalisasi sikap dari Teologi Dispensasionalisme yang menyatakan bahwa Gereja sama sekali berbeda dan tidak sama dengan Israel. Ketiga, pandangan Teologi Sisa (Remnant Theology) yang memandang Gereja dan Israel dalam segi tertentu tumpang tindih (overlap).

Dalam Teologia Penggantian (supersessionism atau replacement theology) pada hakikatnya mengajarkan bahwa gereja telah meggantikan Israel dalam rencana Allah. Gereja adalah pengganti Israel dan banyak janji yang diberikan kepada Israel dalam Alkitab digenapi dalam Gereja Kristen, bukan dalam Israel. Jadi nubuat-nubuat dalam Alkitab yang berhubungan dengan berkat dan pemulihan Israel ke Tanah Perjanjian "dirohanikan" atau "dialegorikan" sebagai janji-janji berkat Allah untuk gereja.22 Ada dua alasan timbulnya pemahaman bahwa gereja menjadi Israel baru, menurut Karman:23 Pertama, dalam menggambarkan gereja beberapa penulis PB yang khas untuk Israel PL. Dalam LXX umat

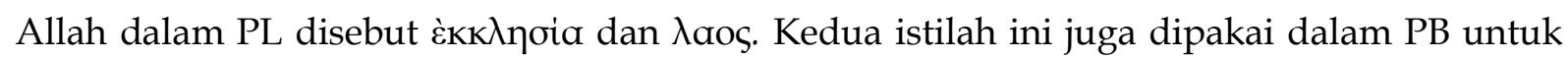
gereja. Dua ayat paralel sulit menyangkal kesamaan antara umat Allah dalam PL dan PB (bd. Kel. 19:5, 6 dan 1 Ptr.2:9). Kedua, ketika PB mengutip beberapa teks PL, kutipan-kutipan itu digenapi dalam Kristus atau dalam gereja seperti contoh berikut dalam Hosea 11:1 yang dicatat oleh Maitus sebagai penggenapan nubuatan, "Hal itu terjadi supaya genaplah yang difirmankan Tuhan oleh nabi: "Dari Mesir Kupanggil Anak-Ku." (Mat.2:15). Matius mengutip Hosea untuk mengatakan bahwa anak yang dipanggil dari Mesir adalah Yesus, padahal Hosea memaksudkannya sebagai bangsa Israel. Demikian dengan ayat-ayat yang lain, sebuah istilah menunjuk kepada dua realitas berbeda, namun dalam hal tertentu mirip (prinsip analogi). Namun demikian pandangan ini demikian dalam beberapa dekade ini goyah. ${ }^{2425}$ Tanpa disangka-sangka orang Yahudi berhasil mendirikan Israel pada tahun 1948. Jikalau

${ }^{20}$ Wikipedia, https://id.wikipedia.org/wiki/Yahudi_Mesianik diakses Oktober 2021.

21John. J. Parsons, "Israel and the Church - Understanding Some Tehological Options," Www.Hebrew4christians.Com, last modified 2013, accessed September 1, 2021, https://www.hebrew4christians.com/Articles/Israel/israel.html.

22Org GotQuestions, "Apa Itu Teologi Penggantian?," Gotquestions.Org, accessed September 1, 2021, https://www.gotquestions.org/Indonesia/teologia-penggantian.html.

${ }^{23}$ Yonky Karman, Bunga Rampai Teologi Perjanjian Lama: Dari Kanon Sampai Doa (Jakarta: Gunung Mulia, 2005), 106-107.

24 Ibid., 105.

${ }^{25}$ Adam Gregerman, "Superiority without Supersessionism: Walter Kasper, The Gifts and the Calling of God Are Irrevocable , and God's Covenant with the Jews," Theological Studies 79, no. 1 (March 23, 2018): 36-59, http://journals.sagepub.com/doi/10.1177/0040563917744652.

116 - J.R. Pangaribuan, Pilihan Allah Atas Israel: Masih Relevankah di Masa Kini? 
Israel sudah dihukum Allah, dan tidak ada masa depan untuk bangsa Yahudi lagi, bagaimana menjelaskan mujizat bertahannya orang Yahudi dalam 2000 tahun belakangan sekalipun adanya berbagai upaya untuk memusnahkan mereka? Bagaimana menjelaskan mengapa dan bagaimana Israel muncul kembali sebagai suatu bangsa di abad ke-20 setelah hilang lenyap selama 1900 tahun? Jadi pandangan ini tidak memadai sebab menyangkal keberadaan Israel yang tampaknya selalu mengalami providensia Allah.

Dalam pandangan dispensasionalis (Separation Theology) Israel dan Gereja adalah berbeda dan terpisah. Keduanya tidak boleh dicampuradukkan atau digunakan dalam pengertian yang sama, demikian juga dengan bangsa-bangsa lain. Jadi ada perbedaan yang dipertahankan dalam Alkitab antara Israel, orang-orang Yahudi, dan Gereja. Kekhasan karakter gereja sebagai Tubuh Kristus adalah rangkap dua. Kedua sifat ini khas Perjanjian Baru, Gereja sebagai manusia baru, satu tubuh (baik Yahudi dan bangsa-bangsa non Yahudi), dan kehadiran kehadiran Kristus di tengah para anggota tubuh itu tidak ada pada masa Perjanjian Lama, bahkan pada masa Tuhan kita di dunia. Istilah Israel terus dipertahankan untuk semua keturunan Abraham secara jasmani (bukan rohani) setelah gereja dilembagakan, dan tidak disamakan dengan gereja. ${ }^{26}$ Bagi para dispensasionalis ada pemenuhan yang tertunda - yakni pemerintahan Mesias di atas takhta Daud, yang akan dipenuhi dalam masa melenium, suatu kerajaan yang bersifat jasmani sekaligus rohani., Setelah pengangkatan gereja (1Tesalonika 4:13-18), Allah akan memulihkan Israel kembali sebagai fokus utama rencana-Nya. Kesengsaraan Besar merupakan Peristiwa pertama pada masa ini menurut Wahyu 6-19. Penokan dunia terhadap Kristus akan menerima hukuman, sebelum kedatangan Mesias kedua kalinya, pada akhirnya Israel akan siap menerima Kristus setelah melewati penganiayaan pada masa Kesengsaraan Besar. Sisa Israel yang masih bertahan pada masa Kesengsaraan Besar akan diselamatkan dan Tuhan akan mendirikan Kerajaan-Nya di atas bumi dengan Yerusalem sebagai ibukota. Israel akan menjadi Bangsa utama, saat Kristus memerintah sebagai Raja, dan para duta dari berbagai bangsa akan datang ke Yerusalem untuk menghormati dan menyembah Yesus Kristus sang Raja. Gereja akan kembali memerintah bersama dengan Dia dalam seribu tahun secara harafiah (Wahyu 20:1-5). Di sini golongan dispensasionalis melihat peran Israel sebagai bangsa dipulihkan dan diperbaharui pada zaman millennium. ${ }^{27}$ Menurut Pasrons dalam prakteknya hal ini memiliki pengaruh yang tidak disadari mengurangi relevansi Kitab Suci Perjanjian Lama, atau paling tidak mensubordinasikannya kepada status praktikal yang lebih rendah daripada suratan Paulus dalam Perjanjian Baru. ${ }^{28}$

Gagasan sisa umat dalam PL (Remnat Theology), memainkan peranan penting dalam $\mathrm{PB},{ }^{29}$ gagasan tersebut membantu menjelaskan mengapa tidak semua orang Israel menerima Yesus sebagai Mesias yang dinantikan. Yesus sendiri menyinggung visi Yesaya (Yes.6:9-10)

\footnotetext{
${ }^{26}$ Charles C. Ryrie, Dispensationaslism Dari Zaman Ke Zaman (Malang: Gandum Mas, 2005), 186. 27Ibid., 200.

28Parsons, "Israel and the Church - Understanding Some Tehological Options."

${ }^{29}$ Ryken, Wilhoit, and III, Kamus Gambaran Alkitab, 1028.
} 
bahwa tidak semua orang menanggapi perkataan-Nya dengan iman (Mark.4:10-13). Paulus juga menunjuk kepada gambaran PL untuk memahami ketidakpercayaan Israel: “Akan tetapi firman Allah tidak mungkin gagal. Sebab tidak semua orang yang berasal dari Israel adalah orang Israel" (Rom 9:6). Memang benar bahwa Yesus tidak menggunakan konsep umat tersisa secara eksplisit. ${ }^{30}$ Namun, bukankah itu adalah pertanda bahwa murid-murid sebagai "kawanan kecil" (Luk.12:32) adalah referensi yang tepat terhadap konsep Perjanjian Lama, yaitu Israel sebagai domba gembalaan Allah, sekarang terwujud dalam murid-murid Yesus (Yes 40:11)? Bukankah ini dengan tepat menunjukkan bahwa mereka adalah umat tersisa yang masih tetap setia? Ini bukan berarti suatu kelompok yang terpisah, mereka adalah bagian dari Israel secara etnis. ${ }^{31}$ Teologi Paulus tentang pilihan yang dijabarkan dalam Rom 9-11 secara penting pada gagasan-gagasan dalam PL, tentang sisa umat. Sekalipun Israel mengeraskan hati, Paulus yakin bahwa "Allah tidak menolak umat-Nya" (Rom 11:2), 32 dan sebagai bukti, ia mengutip contoh dari keputusasaan Elia: "Hanya aku seorang dirilah yang masih hidup, dan mereka ingin mencabut nyawaku" (Rom 11:3, mengutip 1 Raja 19:10), “Tetapi bagaimanakah firman Allah kepadanya?" Paulus bertanya, dan jawaban Allah, "'Aku masih meninggalkan tujuh ribu orang bagi-Ku, yang tidak pernah sujud menyembah Baal' (1 Raja 19:18). Demikian juga pada waktu ini ada tinggal suatu sisa, menurut pilihan kasih karunia" (Rom 11:4-5). Kepada umat tersisa yang percaya ini telah ditambahkan orang-orang bukan-Yahudi yang percaya. ${ }^{33}$ Gambaran Paulus tentang pohon zaitun mengemukakan kesatuan umat Allah yang lama - Israel - dan gereja. Gereja yang terdiri dari orang Yahudi dan bukan-Yahudi telah menjadi cabang-cabang dari pohon zaitun - umat Allah - Israel yang benar. Cabangcabangnya yang alami - orang-orang Yahudi yang tidak percaya - patah, dan tunas-tunas liar - orang-orang bukan-Yahudi yang percaya - dicangkokkan kepada pohon itu.

\section{Implikasi Teologis}

Dalam teologi Penggantian Gereja melampaui dan menggantikan Israel (diskontinuitas) dan meninggalkan Israel begitu saja tanpa masa depan penebusan. Sedangkan dalam pandangan dispensasional terjadi pemisahan antara Israel dan Gereja; pertanyaannya adalah bagaimana mereka saling berhubungan khususnya dalam millennium sampai kekekalan? Teologi Sisa mencoba mendamaikan posisi dilematis ini dengan memandang bahwa Gereja adalah bagian dari sisa Israel yang setia yang menerima Yesus sebagai Mesias. Sisa yang setia inilah yang disebut "Israel milik Allah" dalam Galatia 6:6.

Pemahaman Eskatologis memengaruhi sikap dan pandangan teologis terhadap Israel dan Gereja. Pandangan premilenialisme merupakan pandangan teologis memberi tempat bagi pemulihan bagi bangsa Israel dan bagi penggenapan hurufiah nubuatan-nubuatan tentang

${ }^{30}$ George Eldon Ladd, Teologi Perjanjian Baru Jilid 1 (Jakarta: Yayasan Kalam Hidup, 2002), 139.

${ }^{31}$ Johnson, "Paul and ' the Israel of God ': An Exegetical and Eschatological Case-Study."

${ }^{32}$ Roy Charly H. P. Sipahutar, "ISRAEL BARU (Interpretasi Kritis Atas Teologi Paulus Tentang Israel Di Dalam Roma 9:6-8 Dan 11:23-24)," Jurnal Teologi Cultivation 3, no. 1 (2019): 98-112.

${ }^{33}$ George Eldon Ladd, Teologi Perjanjian Baru Jilid 2 (Jakarta: Yayasan Kalam Hidup, 2002), 328.

118 - J.R. Pangaribuan, Pilihan Allah Atas Israel: Masih Relevankah di Masa Kini? 
damai sejahtera dan berkat yang telah dinubuatkan oleh Yesaya dan nabi-nabi lainnya. ${ }^{34}$ Tetapi dukungan terhadap Israel oleh kaum premilenialis ini menurut Karman harus dikritisi. Pandangan teologia yang premilenialis mendukung zionisme.35 Tindak kekerasan yang menyertai pencaplokan Palestina itu tidak sesuai dengan ajaran Firman Tuhan. Permasalahan yang timbul kemudian juga ialah ternyata bangsa Israel saat ini adalah bangsa yang bersifat sekuler. Israel sebagai umat Allah tidak identik dengan Negara Israel moderen. Karman mengingatkan bahwa "Tuhan tidak terikat perjanjian dengan Negara Israel sekarang, sebuah negara demokrasi moderen yang dasar negaranya bersifat sekuler (bandingkan pemerintahan bersifat teokrasi dalam Perjanjian Lama)". Dengan demikian Israel sebagai bangsa tidak bisa kita pahami sebagai kelanjutan umat Allah, sebab dalam prakteknya Negara Israel sekarang tidak mencerminkan layaknya umat Allah, mereka sendiri tidak mau menerima Yesus sebagai Mesias yang dijanjikan. Bahkan menurut Brauch dalam komentar terhadap Roma 11:26 tidak ada indikasi di manapun dalam pasal 11 dari surat Paulus kepada Jemaat di Roma adanya pandangan pertobatan Israel sebagai suatu bangsa, terletak pada satu wilayah tertentu dari suatu wilayah pemukiman (real estate). ${ }^{36}$ Sebab pada zaman Paulus pun bangsa Yahudi sudah lebih banyak yang tinggal di luar Palestina (diaspora) dari pada yang tinggal di dalam (di Palestina).

Sejauh ini pandangan Teologi Sisa lebih dapat menjelaskan arti penting pilihan Allah atas Israel dan dapat memberikan ruang bagi Gereja dalam suatu hubungan dengan Israel. Remnant Theology mengklaim hubungan Gereja dan Israel yang "overlap" saling tumpang tindih dalam hal tertentu. ${ }^{37}$ Yang perlu kita ingat adalah bahwa Allah tidak mungkin menolak umat-Nya (yakni Israel) seperti dikatakan oleh Rasul Paulus dalam Roma 11:1. Konteks itu memperlihatkan bahwa Alkitab sedang membicarakan bangsa Isrsel yang betul-betul dan memperlihatkan bahwa Allah tidak mengubah pikiran-Nya tentang semua janji-Nya. Ingat juga bahwa kedua belas rasul akan menghakimi, atau memerintah dua belas suku Israel (Mat 19:28; Luk 22:30). Jelaslah, hal ini memberi ruang terjadinya pemulihan harfiah bangsa Israel. Tidak mungkin Gereja dapat dibagi menjadi dua belas suku Israel. ${ }^{38}$ Janji pemulihan Israel yang belum digenapi seperti janji-janji nubuatan Allah yang lain akan digenapi dalam zaman millenium, bukan dalam Negara Israel sekarang ini.

\section{KESIMPULAN}

Gereja dimulai dari antara bangsa Yahudi, tetapi sebagai bangsa mereka menolak Mesias- Yesus Kristus, dan karenanya mereka berada di bawah murka Allah. Tetapi Allah tidak menolak pilihan-Nya, Allah telah memilih satu sisa (remnant) dari antara bangsa itu.

\footnotetext{
${ }^{34}$ William W. Menzies and Stanley M. Norton, Doktrin-Doktrin Alkitab, Menurut Pandangan Pentakosta (Malang: Gandum Mas, 2003), 225.

35Karman, Bunga Rampai Teologi Perjanjian Lama: Dari Kanon Sampai Doa, 101.

36Walter Kaiser Jr. ; Peter H. Davies; F.F. Briuce; Manfred T. Brauch, Hard Sayings of The Bible (United States: InterVarsity Press, 1996), 570.

37Parsons, "Israel and the Church - Understanding Some Tehological Options."

38Menzies and Norton, Doktrin-Doktrin Alkitab, Menurut Pandangan Pentakosta, 224.
} 
Israel yang percaya dan menerima Mesias adalah sisa (remnant) yang diselamatkan, sehingga pilihan Allah atas bangsa Israel tetap relevan hingga masa kini. Hadirnya Gereja tidak berarti menggantikan Israel umat Allah, tetapi Israel yang sejati adalah umat yang percaya terdiri dari orang Yahudi dan non Yahudi yang percaya. Karena itu Gereja tidak perlu mendukung cara-cara yang bertentangan dengan hak azasi dalam mewujudkan negara Israel merdeka (zionisme). Tetapi juga tidak perlu sikap yang antipati (antisemit) terhadap Israel, sebab Allah sendiri masih tetap memilih Israel dan berdaulat atasnya untuk menyelamatkannya dengan bukti adanya orang-orang Yahudi yang percaya dengan mempertahankan keyahudiannya seperti pada kelompok Yahudi Mesianik.

\section{DAFTAR PUSTAKA}

Abulof, Uriel. “The Roles of Religion in National Legitimation: Judaism and Zionism's Elusive Quest for Legitimacy." Journal for the Scientific Study of Religion 53, no. 3 (September 3, 2014): 515-533. http://www.jstor.org/stable/24644225.

BibleWorks. “BibleWorks 8," 2018.

Brauch, Walter Kaiser Jr. ; Peter H. Davies; F.F. Bruce; Manfred T. Hard Sayings of The Bible. United States: InterVarsity Press, 1996.

Carty. “Martin Luther's Anti-Judaism and Its Political Significance." Antisemitism Studies 3, no. 2 (2019): 317. https://www.jstor.org/stable/10.2979/ antistud.3.2.06.

Coren, Michel. "The Reformation at 500: Grappling with Martin Luther's Anti-Semitic Legacy." Last modified 2017. https://www.macleans.ca/opinion/the-reformation-at500-grappling-with-martin-luthers-anti-semitic-legacy/.

Dwiastuti, Ilmi. “The Roots of Israel-Palestine Conflict: A Political Culture Analysis.” AEGIS : Journal of International Relations 4, no. 2 (2021): 19-33.

Fanning, Don. "Apostolic History of the Early Church." History of Global Missions (2009). https://digitalcommons.liberty.edu/cgm_hist/1\%0A.

Fox, "Thor. Are Messianic 'Jews'?" https://www.myjewishlearning.com/article/messianic-judaism/.

GotQuestions, Org. “Apa Itu Teologi Penggantian?" Gotquestions.Org. Accessed September 1, 2021. https://www.gotquestions.org/Indonesia/teologia-penggantian.html.

Gregerman, Adam. "Superiority without Supersessionism: Walter Kasper, The Gifts and the Calling of God Are Irrevocable, and God's Covenant with the Jews." Theological Studies 79, no. 1 (March 23, 2018): 36-59. http://journals.sagepub.com/doi/10.1177/0040563917744652.

Hallward, Maia, and By Maia Hallward. "Pursuing \&quot; Peace\&quot; in Israel/Palestine." Journal of Third World Studies 28, no. 1 (2011): 185-202. http:/ / digitalcommons.kennesaw.edu/facpubs.

Hauger, Martin. "Martin Luther and the Jews: How Protestant Churches in Germany Deal with the Reformer's Dark Side." Theology Today 74, no. 3 (October 24, 2017): 225-234. http://journals.sagepub.com/doi/10.1177/0040573617721913.

120 - J.R. Pangaribuan, Pilihan Allah Atas Israel: Masih Relevankah di Masa Kini? 
History.Com Editors. "Israel." Last modified 2017. https:/ /www.history.com/ topics/middleeast/history-of-israel.

Johnson, S Lewis. "Paul and ' the Israel of God ': An Exegetical and Eschatological CaseStudy." Master's Seminary Journal 1, no. Spring (2009): 41-55.

Karman, Yonky. Bunga Rampai Teologi Perjanjian Lama: Dari Kanon Sampai Doa. Jakarta: Gunung Mulia, 2005.

Klar, Yechiel, Noa Schori-Eyal, and Yonat Klar. “The 'Never Again' State of Israel: The Emergence of the Holocaust as a Core Feature of Israeli Identity and Its Four Incongruent Voices." Journal of Social Issues 69, no. 1 (March 2013): 125-143. https:// onlinelibrary.wiley.com/doi/10.1111/josi.12007.

Kuhl, Dietrich. Sejarah Gereja 1: Gereja Mula-Mula Di Dalam Lingkungan Kebudayaan Yunani Romawi (30-500). Batu: Departemen Literatur, Yayasan Persekutuan Pekabaran Injil Indonesia, 1992.

Ladd, George Eldon. Teologi Perjanjian Baru Jilid 1. Jakarta: Yayasan Kalam Hidup, 2002.

- - - . Teologi Perjanjian Baru Jilid 2. Jakarta: Yayasan Kalam Hidup, 2002.

Menzies, William W., and Stanley M. Norton. Doktrin-Doktrin Alkitab, Menurut Pandangan Pentakosta. Malang: Gandum Mas, 2003.

Museum, United States Holocaust Memorial. "Final Solution Overview." Holocaust Encyclopedia, n.d. https://encyclopedia.ushmm.org/content/id/article/final-solutionoverview.

Parsons, John. J. "Israel and the Church - Understanding Some Theological Options." Www.Hebrew4christians.Com. Last modified 2013. Accessed September 1, 2021. https://www.hebrew4christians.com/Articles/Israel/israel.html.

Reditya, Tito Hilmawan. "Kekejaman Holocaust Nazi, Korban 'Dikemas Seperti Sarden.'” Kompas.Com.

Reuters. "Sejarah Panjang Konfrontasi Hamas Dan Israel." Www.Voaindonesia.Com. Last modified 2021. Accessed September 1, 2021. https:/ / www.voaindonesia.com/a/ sejarahpanjang-konfrontasi-hamas-dan-israel/5901008.html.

Ryken, Leland, James C. Wilhoit, and Tremper Longman III. Kamus Gambaran Alkitab. Surabaya: Momentum, 2011.

Ryrie, Charles C. Dispensationaslism Dari Zaman Ke Zaman. Malang: Gandum Mas, 2005.

Siapera, Eugenia, Graham Hunt, and Theo Lynn. "\#GazaUnderAttack: Twitter, Palestine and Diffused War." Information Communication and Society 18, no. 11 (2015): 1297-1319.

Sipahutar, Roy Charly H. P. “ISRAEL BARU (Interpretasi Kritis Atas Teologi Paulus Tentang Israel Di Dalam Roma 9:6-8 Dan 11:23-24)." Jurnal Teologi Cultivation 3, no. 1 (2019): 98112. 